\title{
PHOSPHATE SLUDGE: OPPORTUNITIES FOR USE AS A FERTILIZER IN DEFICIENT SOILS
}

\author{
Ayoub Haouas ${ }^{1}$, Cherkaoui El Modafar ${ }^{2}$, Allal Douira ${ }^{3}$, Saâd Ibnsouda-Koraichi ${ }^{4}$, \\ Abdelkarim Filali-Maltouf ${ }^{5}$, Abdelmajid Moukhli ${ }^{6}$ and Soumia Amir ${ }^{1, *}$ \\ ${ }^{1}$ Laboratoire Polyvalent en Recherche et Développement, Faculté Polydisciplinaire, Université Sultan Moulay Slimane, Beni Mellal, \\ Morocco \\ ${ }^{2}$ Laboratoire d'Agrobiotechnologie et Bioingénierie, Faculté des Sciences et Techniques, Université Cadi Ayyad, Marrakech, Morocco \\ ${ }^{3}$ Laboratoire de Botanique Biotechnologie et de Protection des Plantes, Faculté des Sciences, Université Ibn Tofail, Kenitra, Morocco \\ ${ }^{4}$ Laboratoire de Biotechnologie Microbienne et Molécules Bioactives, Faculté des Sciences et Techniques, Université Sidi Mohamed Ben \\ Abdellah, Fès, Morocco \\ ${ }^{5}$ Laboratoire de Microbiologie et Biologie Moléculaire, Faculté des Sciences, Université Mohammed V, Rabat, Morocco \\ ${ }^{6}$ Unité de Recherche d'Amélioration génétique des plantes, Institut national de la Recherche Agronomique, Marrakech, Morocco
}
Article Info:
Received:
23 July 2020
Revised:
4 May 2021
Accepted:
14 June 2021
Available online:
11 September 2021
Keywords:
Sandy soil
Phosphate
Clay
Agriculture
Circular economy
Nutrients

\section{ABSTRACT}

Phosphate sludge (PS) is an industrial by-product produced in huge quantities by the phosphate beneficiation plants in Morocco. In order to valorize this by-product, it was examined for its potential use as a soil fertilizer. The physicochemical properties, elemental and mineral content, morphological structure, and component stability of raw PS were investigated. In addition, pathogenicity, phytotoxicity, and the capacity of PS to promote plant growth in deficient sandy soil have been studied. The obtained results showed that PS was characterized by low values of moisture $(2.10 \%)$, electrical conductivity $(\mathrm{EC})(0.77 \mathrm{mS} / \mathrm{cm})$, and organic matter $(\mathrm{OM})(0.61 \%)$, with a slightly alkaline $\mathrm{pH}$ (8.20). Nevertheless, this material carried interesting content of fertilizing elements such as phosphorus (P2O5) of $20.01 \%$, calcium (CaO) of $39.72 \%$, and magnesium (MgO) of $2.33 \%$. Thus, PS did not present any pathogenic or phytotoxic risk with a high increase in tomato plant growth than the control of only soil. In conclusion, the results of this study could provide the primary practical guidance for the PS application in deficient soils characterized by sandy texture.

\section{INTRODUCTION}

In Africa, the agricultural sector faces environmental challenges that limit its development. Approximately $20 \%$ of arable land is currently not cultivable, and a further sharp decline is expected by 2080 (Fao, 2009). In addition, representative soils in Africa are sandy soils characterized by a deficient state of nutrients and low water-holding capacity resulting in low yields (Kihara et al., 2020). Fertilizing sandy soil is a promising solution that has been widely adopted to improve smallholder-farming systems, particularly in developing countries. However, due to the simultaneous increase in demand for phosphate fertilizers and the continuous depletion of phosphate reserves, the focus is today on the opportunities of recovering phosphate ores from secondary sources (i.e., low-grade ore and residues) (Karunanithi et al., 2015).

Morocco, represented by Office Chérifien du Phosphate (OCP), is a worldwide leader in the phosphate-based products industry. Moroccan phosphate ore is processed through a combination of successive enrichment steps involving crushing, screening, washing and flotation (Khasawneh and Doll, 1979; Boujlel et al., 2019). The washing and flotation steps generate large quantities of PS, reaching 28 million metric tons in 2010 (Haouas et al., 2021a). PS represents major economic and environmental problems, which by its accumulating induced a loss of recyclable materials, forms dikes, disfigures the landscape and reduces arable lands (Haouas et al., 2020). Until this time, few studies aimed to find appropriate ways for PS valorization, including the production of light aggregates (Loutou et al., 2013), geopolymers (Moukannaa et al., 2018) and composting (Haouas et al., 2021b).

PS as a phosphate rock by-product has the potential to be a sustainable, low cost and permanently available substrate for improving deficient soils, which will open up ways to its integration into the circular economy. Furthermore, the reuse of PS for land application can significantly reduce disposal costs and provide a source of mineral nutrients for many crops (Hakkou et al., 2018; Haouas et al., 
2021a). A standardized characterization of PS is required, as is the tracing of the guidelines for its possible use as an amendment (FAO, 2009). Until now, there are no guidelines for the safe use of PS in agriculture. For this reason, the present study had as objectives, (i) the characterization of physicochemical, mineralogical and structural properties of the PS, (ii) the evaluation of its safety in terms of phytotoxic and pathogenic factors, and (iii) the assessment of the fertilizing capacity using agronomic essay in sandy soil.

\section{MATERIALS AND METHODS}

\subsection{Sampling}

PS was collected from a deposit area around the phosphate laundry plant managed by OCP, SA in Khouribga City (center of Morocco) (32 $\left.44^{\prime} 16.2^{\prime \prime} \mathrm{N} ; 6^{\circ} 50^{\prime} 48.2^{\prime \prime} \mathrm{W}\right)$, which was produced between 1990 and 2000 (Figure 1a). The total quantity of $10000 \mathrm{Kg}$ of PS samples was taken from different points, and homogeneous subsamples (Figure 1b) were prepared using the quartering method (Atif et al., 2020).

As illustrated in Figure 2, the production chain of PS starts with the arrival of raw phosphate from the exploitation unit to the ore enrichment plants. The phosphate-rich fraction was separated from the gangue minerals by a series of enrichment treatment steps, started by screening through $3.15 \mathrm{~mm}$ sieves. The fraction greater than 3.15 $\mathrm{mm}$ is considered as sterile, while the particles less than $3.15 \mathrm{~mm}$ are divided into three parts of $>160 \mu \mathrm{m}, 160 \mu \mathrm{m}$ $40 \mu \mathrm{m}$, and $<40 \mu \mathrm{m}$ during the washing process. The part of $<40 \mu \mathrm{m}$ constitutes the first part of the PS. The part between $3.15 \mathrm{~mm}$ and $160 \mu \mathrm{m}$ is recovered as a concentrated phosphate, and the last part between $160 \mu \mathrm{m}$ and $40 \mu \mathrm{m}$ has been further treated by flotation. At this stage, the phosphate particles between $125 \mu \mathrm{m}$ and $160 \mu \mathrm{m}$ are separated from the other gangue minerals that make up the second part of the PS. The PS is then deposited on the surrounding lands of the enrichment factories (Haouas et al. 2021b).

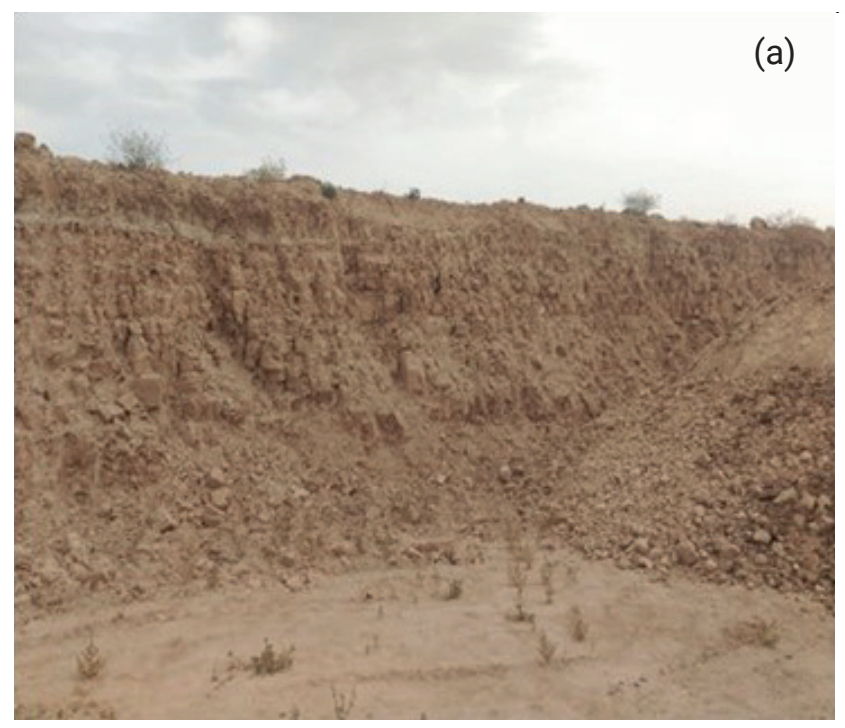

\subsection{Physicochemical and elemental analysis}

The moisture content was determined immediately after sampling in an oven at $105^{\circ} \mathrm{C}$ for 48 hours. Measurement of $\mathrm{pH}$ and the EC was performed on PS fresh sample of 10 $\mathrm{g}$ stirred in $100 \mathrm{ml}$ of distilled water using $\mathrm{pH}$ meter (PHSJ$3 F$ ) and conductivity meter (DDS-12DW) (AFNOR, 2000).

The ash content was calculated after calcination in a muffle furnace at $550^{\circ} \mathrm{C}$ for 6 hours using the following formula (Amir et al., 2005):

Ash $(\%)=100-\left(100 \times \frac{W d-W c}{W d}\right)$

Wd: dry weight and Wc: calcined weight.

Total organic carbon (TOC) was determined by Anne's method (Tallou et al., 2020). This method combined the oxidation of $\mathrm{OM}$ with potassium dichromate $\left(\mathrm{K}_{2} \mathrm{Cr}_{2} \mathrm{O}_{7}\right)(0.4 \mathrm{~N})$ in an acidic medium and the back-titration of excess potassium dichromate by Mohr salt $\left(\mathrm{Fe}\left(\mathrm{NH}_{4}\right)_{2}\left(\mathrm{SO}_{4}\right)_{2} * 6 \mathrm{H}_{2} \mathrm{O}\right)(0.2$ $\mathrm{N})$. The OM content was determined by dividing the COT by 1.72 (Amir et al., 2005). The total Kjeldahl nitrogen (TKN) was measured by mineralization in the presence of sulfuric acid (98\%) and the Kjeldahl catalyst. The steam distillation transformed the ammonium ions $\left(\mathrm{NH}_{4}^{+}\right)$into ammonia $\left(\mathrm{NH}_{3}\right)$ through the alkaline medium of $\mathrm{NaOH}$ (40\%). The $\mathrm{NH}_{3}$ molecules are recovered in boric acid and then dosed by a volumetric acid/base assay (Chen et al., 2010).

Inductively coupled plasma - optical emission spectrometry (ICP-OES, THERMO ICAP 6500 DUO) was used to determine the total and water-soluble fraction of the elements. The anions were analyzed using ion chromatography with a liquid chromatograph (Metrohm, Switzerland). Analysis of the major elements of a finely ground dry sample was performed using an EPSILON 4 energy dispersive $\mathrm{X}$-ray fluorescence spectrometer (EDXRF).

The phosphorus $(P)$ fractionation procedure was performed based on sequential extraction, with a sample: solution ratio of $1: 50$. Indeed, for soluble $P$, the sample was treated with a solution of $\mathrm{NH}_{4} \mathrm{Cl}(1 \mathrm{M}), \mathrm{NH}_{4} \mathrm{~F}$ (5 M at $\mathrm{pH} 7$ ) for the $\mathrm{P}$ bound to aluminum (Al), $\mathrm{NaOH}(0.1 \mathrm{M})$ for $\mathrm{P}$

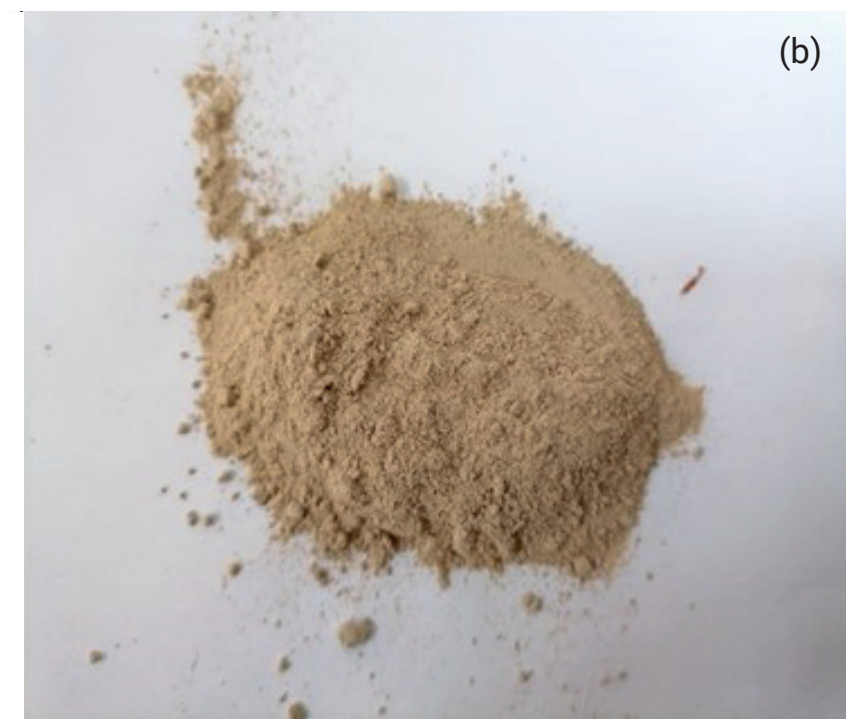

FIGURE 1: a) PS sampling site, b) PS subsample. 


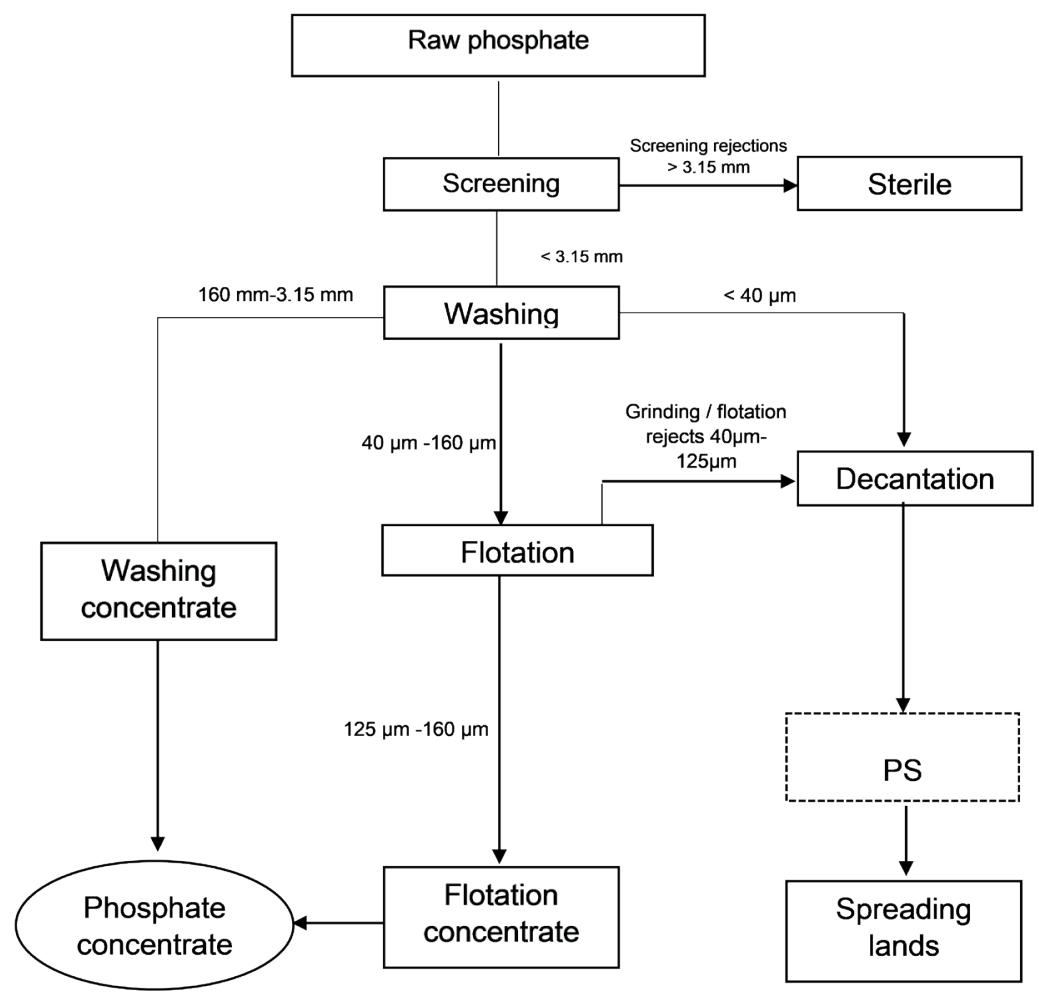

FIGURE 2: PS generation chain during phosphate treatment.

bound to iron (Fe), and finally by $\mathrm{H}_{2} \mathrm{SO}_{4}(0.5 \mathrm{M})$ for $\mathrm{P}$ bound to calcium $(\mathrm{Ca})$, in this order. After each extraction, the supernatant was filtered through $0.2 \mu \mathrm{m}$ filter paper, and the concentration of $\mathrm{P}$ extracted was determined using the molybdenum blue method (Chang and Jackson, 1957). In contrast, organic $P$ was measured according to the Bray and Kurtz method (1945).

\subsection{PS characterization}

\subsubsection{Thermal stability}

Thermal stability is an important criterion to consider when studying the stability of organic substrates targeted for agricultural use. Thermogravimetric and differential thermal (TGA/DTA) analyses were performed to investigate the OM stability of PS using a TA instrument (SDT Q600) equipped with platinum crucibles and a heating rate of $10^{\circ} \mathrm{C} / \mathrm{min}$ from 25 to $1000^{\circ} \mathrm{C}$ in an oxidizing atmosphere.

\subsubsection{Fourier Transform Infrared- FTIR}

FTIR spectroscopy (PerkinElmer 1600) was used to determine the functional groups of raw PS and monitor their relative changes during the heating process. For this purpose, a mixture of $1 \mathrm{mg}$ (dry weight) of each sample and $400 \mathrm{mg}$ of potassium bromide $(\mathrm{KBr})$ was prepared as pellets by vacuum compression. Spectra of raw and heated PS samples were obtained after analysis over a range of $400-4000 \mathrm{~cm}^{-1}$ at $16 \mathrm{~nm} / \mathrm{sec}$.

\subsubsection{Mineralogy and structure}

Mineral phases of PS were characterized by X-ray diffraction (XRD, Philips X'Pert MPD diffractometer) equipped with a copper anticathode ( $\mathrm{Ka} 1 / 41.5418 \mathrm{~A}^{\circ}$ ) operating at $40 \mathrm{kV}$ and $40 \mathrm{~mA}$. The analysis was carried out in the interval of angles 2 theta (20) between $5^{\circ}$ and $70^{\circ}$. The processing of the diffractogram data obtained was carried out using the X'Pert High Score software. The phase indexing is based on comparing $2 \theta$ values with the ICSD database (Inorganic Crystal Structure Database). The surface morphology of the PS was observed by scanning electron microscopy (SEM) using Vega 3 Tescan microscope with an acceleration voltage of $20 \mathrm{kV}$.

\subsection{Phytotoxicity evaluation}

The germination test was conducted to monitor the phytotoxicity of PS. The PS extract at a concentration of $10 \%(\mathrm{w} / \mathrm{v})$ was used to moisten 20 seeds of each species of tomato (Solanum Lycopersicum) and maize (Zea mays). Moistened seeds with PS extract and distilled water (control) have been germinated in Petri dishes in the dark at room temperature $\left(28^{\circ} \mathrm{C}\right)$ for 72 hours. The germination index (GI) was calculated using the following equation (Luo et al., 2018):

GI $(\%)=\frac{\text { NGS extract } \times \text { RL extract }}{\text { NGS water } \times \text { RL water }} \times 100$

NGS: Number of Germinated Seeds.

RL: Root Length.

\subsection{Enumeration of pathogens}

PS sample of $10 \mathrm{~g}$ transported from the sampling site in sterile bags at $+4^{\circ} \mathrm{C}$ was stirred in $90 \mathrm{ml}$ of a buffer solution $\left(0.06 \mathrm{M} \mathrm{Na}_{2} \mathrm{HPO}_{4} / \mathrm{NaH}_{2} \mathrm{PO}_{4}\right)(1 / 9 \mathrm{v} / \mathrm{v})$ at $\mathrm{pH}$ 7.6. A series of dilutions $\left(10^{-1}\right.$ to $\left.10^{-10}\right)$ of the sample was made and 
aseptically inoculated into the following selective growth media as described by Atif et al. (2020):

- Tergitol lactose agar for counting fecal coliforms.

- Bile-aesculin agar for fecal streptococci.

- Soybean Casein Digest agar for Escherichia coli.

- Baird Parker agar for Staphylococcus aureus.

- Macconkey agar + Crystal violet was used to count the colorless colonies of Salmonella.

All microbial counts have been calculated on the basis of fresh weight. The concentration of cells in the sample was determined by counting on a known dilution in Petri dishes using the following equation:

$\mathrm{CFU} / \mathrm{g}$ fresh weight $=$ number of colonies $\times$ dilution $\times 100$

CFU: Colony-forming unit.

\subsection{Agronomic essay}

The soil was taken from the Beni Mellal region of Morocco $\left(32^{\circ} 23^{\prime} 58.8^{\prime \prime} \mathrm{N} ; 6^{\circ} 21^{\prime} 46.1^{\prime \prime} \mathrm{W}\right)$. According to the FAO soil classification system, the soil has a sandy loam texture (FAO, 1999). The soil was slightly alkaline (pH 7.97 and EC $=0.28 \mathrm{mS} / \mathrm{cm}$ ) with a low $\mathrm{P}$ and $\mathrm{OM}$ content of $7.4 \mathrm{mg} \cdot \mathrm{kg}^{-1}$ and $0.2 \%$, respectively. The experiment was conducted in pots containing $2 \mathrm{~kg}$ of soil that had been amended with PS concentrations of $0,1,5,10,20,30,40,50$, and $60 \%$. One tomato seedling (Campbell 33 Techni) was placed in each pot; each treatment was replicated five times under greenhouse conditions ( 16 hours of the daily lighting period at temperatures ranged between $20^{\circ} \mathrm{C}$ and $30^{\circ} \mathrm{C}$ ). During the experiment, the pots were regularly watered to maintain the moisture at $60 \%$ of the field capacity. Plants grown in amended soils (treatments) and control without
PS $(0 \%)$ were harvested 80 days after sowing. After that, plant growth parameters were measured, including root lengths, shoot heights, fresh and dry weight of roots and shoots, and the number of lived leaves.

\subsection{Statistical analysis}

Each analysis was replicated three times, and the results were reported as means with standard deviations. ANOVA one-way with post-hoc Tukey HSD test were used to compare the means of plant growth parameters. Significant differences within $(p<0.05)$ are represented by different lowercase letters $(\mathrm{a}-\mathrm{e})$ above the bars.

\section{RESULTS AND DISCUSSION}

\subsection{Physicochemical and elemental properties}

The results obtained from the physicochemical characterization of PS are shown in Table 1. The $\mathrm{pH}$ (8.20) was slightly alkaline, probably due to the high content of water-soluble Ca (Romanos et al., 2019). The EC was low in the range of $0.77 \mathrm{mS} / \mathrm{cm}$, mainly due to the low concentrations of soluble salts such as $\mathrm{K}^{+}, \mathrm{Na}^{+}, \mathrm{PO}_{4}{ }^{3-}$, and $\mathrm{SO}_{4}{ }^{2-}$ (Table 1). This material was relatively dry with an average moisture content of $2.1 \%, 97.2 \%$ as ash and $0.61 \%$ as $\mathrm{OM}$. The elemental composition of the PS sample was dominated by $\mathrm{Ca}(\mathrm{CaO}=39.72 \%), \mathrm{P}\left(\mathrm{P}_{2} \mathrm{O}_{5}=20.01 \%\right)$, and silicon $\left(\mathrm{SiO}_{2}\right.$ $=12.21 \%)$, with slight concentrations of TOC $(0.38 \%)$ and TKN (0.07\%). In addition, the total content of heavy metals in PS such as copper ( $\mathrm{Cu}$ ), cadmium (Cd), chromium $(\mathrm{Cr})$, zinc $(\mathrm{Zn})$, and lead $(\mathrm{Pb})$, is below the limits accepted in European countries for biosolids used in agricultural soils (Collivignarelli et al. 2019). Therefore, many PS elements were present in the water-soluble form at low or undetect-

TABLE 1: The physicochemical characteristics and elemental composition of PS.

\begin{tabular}{|c|c|c|c|c|c|c|c|c|c|}
\hline \multirow{2}{*}{ pH } & \multirow{2}{*}{$\mathrm{EC}(\mathrm{mS} / \mathrm{cm})$} & \multicolumn{3}{|l|}{ Moisture } & \multicolumn{2}{|c|}{ TKN } & OM & \multicolumn{2}{|c|}{ Ash } \\
\hline & & \multicolumn{8}{|c|}{$\%$} \\
\hline $8.20 \pm 0.31$ & $0.77 \pm 0.03$ & $2.10 \pm 0.10$ & \multicolumn{2}{|c|}{$0.38 \pm 0.05$} & \multicolumn{2}{|c|}{$0.07 \pm 0.01$} & $0.61 \pm 0.22$ & \multicolumn{2}{|c|}{$97.20 \pm 2.81$} \\
\hline \multicolumn{10}{|c|}{ Total major elements (wt\%) } \\
\hline $\mathrm{SiO}_{2}$ & $\mathrm{TiO}_{2}$ & $\mathrm{Al}_{2} \mathrm{O}_{3}$ & $\mathrm{Fe}_{2} \mathrm{O}_{3}$ & MgO & $\mathrm{CaO}$ & $\mathrm{Na}_{2} \mathrm{O}$ & $\mathrm{K}_{2} \mathrm{O}$ & \multicolumn{2}{|c|}{$\mathbf{P}_{2} \mathbf{O}_{5}$} \\
\hline 12.21 & 0.23 & 2.98 & 1.18 & 2.33 & 39.72 & 0.66 & 0.41 & \multicolumn{2}{|c|}{20.01} \\
\hline \multicolumn{10}{|c|}{ Total trace elements (ppm) } \\
\hline As & Cd & Co & Mn & $\mathrm{Ni}$ & $\mathrm{Pb}$ & $\mathrm{Cr}$ & $\mathrm{Zn}$ & \multicolumn{2}{|c|}{$\mathrm{Cu}$} \\
\hline 10.34 & 1.01 & 1.50 & 29.59 & 7.06 & 0.21 & 15.95 & 30.78 & \multicolumn{2}{|c|}{4.54} \\
\hline \multicolumn{10}{|c|}{ Anions (mg/L) } \\
\hline $\mathbf{F}^{-}$ & $\mathrm{Cl}^{-}$ & \multicolumn{3}{|c|}{$\mathrm{NO}_{2}^{-}$} & \multicolumn{2}{|c|}{$\mathrm{NO}_{3}^{-}$} & $\mathrm{SO}_{4}{ }^{2-}$ & \multicolumn{2}{|c|}{$\mathrm{PO}_{4}{ }^{3-}$} \\
\hline 2.61 & 4.09 & \multicolumn{3}{|c|}{$<0.10$} & \multicolumn{2}{|c|}{1.72} & 8.34 & \multicolumn{2}{|c|}{$<0.10$} \\
\hline \multicolumn{10}{|c|}{ Water-soluble elements (mg/L) } \\
\hline Mn & B & $\mathrm{Ca}$ & $\mathbf{K}$ & \multicolumn{2}{|c|}{ Mg } & $\mathrm{Na}$ & Si & $\mathrm{Fe}$ & Zn \\
\hline 0.03 & 0.11 & 20.62 & 3.55 & \multicolumn{2}{|c|}{5.12} & 9.96 & 1.80 & 0.04 & 0.01 \\
\hline \multicolumn{10}{|c|}{ P fractions (mg/g) } \\
\hline \multicolumn{2}{|l|}{ Al-P } & \multicolumn{2}{|c|}{ Ca-P } & & \multicolumn{2}{|l|}{ Fe-P } & Olsen P & Org & ic $P$ \\
\hline $0.75 \pm 0.03$ & & 82.60 & & & $1.50 \pm 0$ & & $0.07 \pm 0.001$ & 0.98 & 0.21 \\
\hline
\end{tabular}

wt\%: weight percent; ppm: parts per million 
able concentrations (Table 1). Indeed, the most soluble elements of PS were $\mathrm{Ca}$, sodium $(\mathrm{Na})$, magnesium $(\mathrm{Mg})$, chloride $(\mathrm{Cl})$, and potassium $(\mathrm{K})$, with concentrations of $20.62,9.96,5.12,4.09$, and $3.55 \mathrm{mg} / \mathrm{L}$, respectively. The low dissolution of PS minerals in water can be attributed to the high cation exchange capacity (CEC) of sedimentary phosphate-derived materials (Zhang and Sun, 2017). PS contained a high amount of inorganic $P$ in the form of Al-P, Fe-P, and Ca-P, with values of $0.75,1.5$, and $82.60 \mathrm{mg} / \mathrm{g}$, respectively, when compared to soluble $\mathrm{P}$ (Olsen $\mathrm{P}=0.07$ $\mathrm{mg} / \mathrm{g})$ and organic $\mathrm{P}(0.98 \mathrm{mg} / \mathrm{g})$.

\subsection{Mineralogical and structural characteristics}

The SEM image (Figure 3) shows good porosity of the PS structure, which is $7.01 \%$ in the average pore area and $8.98 \pm 3.43 \mu \mathrm{m}$ in the pore size. In addition, the SEM image reveals the presence of several mineral phases characterized by XRD as carbonate fluorapatite (50\%), dolomite (24\%), calcite $(11 \%)$, quartz $(8.5 \%)$, and smectite $(6.5 \%)$ (Figure 4). A large part of these minerals is small particles (less than $2 \mathrm{~m}$ ), giving the PS a clayey appearance. The identified minerals in PS are inert microcrystals poorly wa-

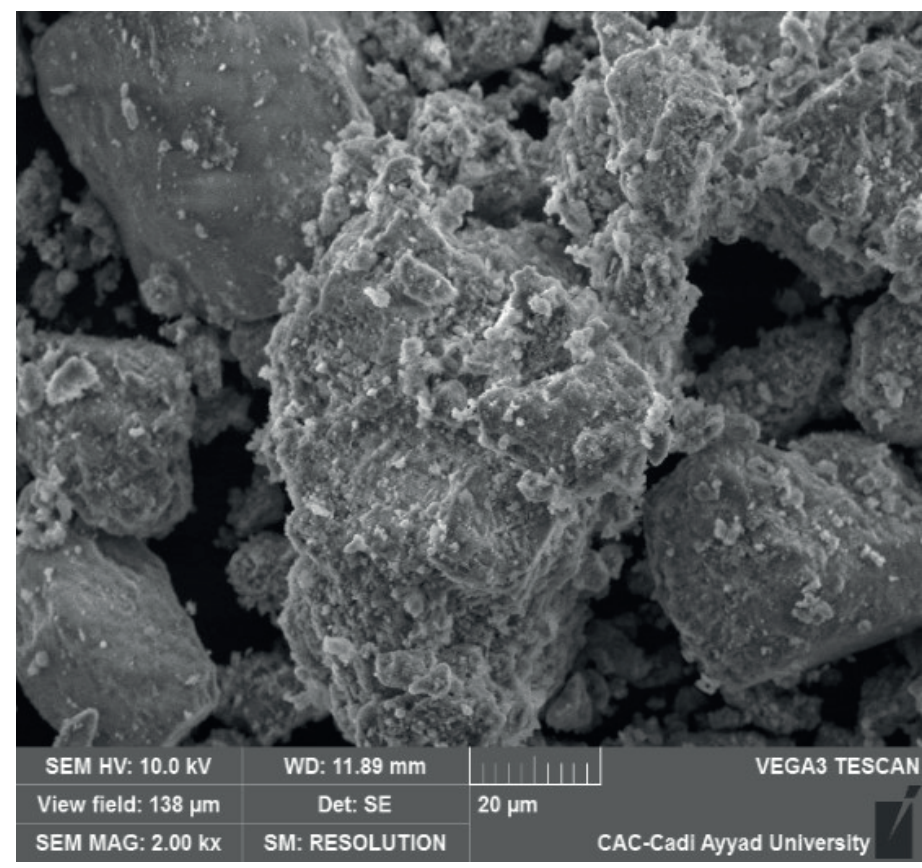

FIGURE 3: PS picture by SEM.

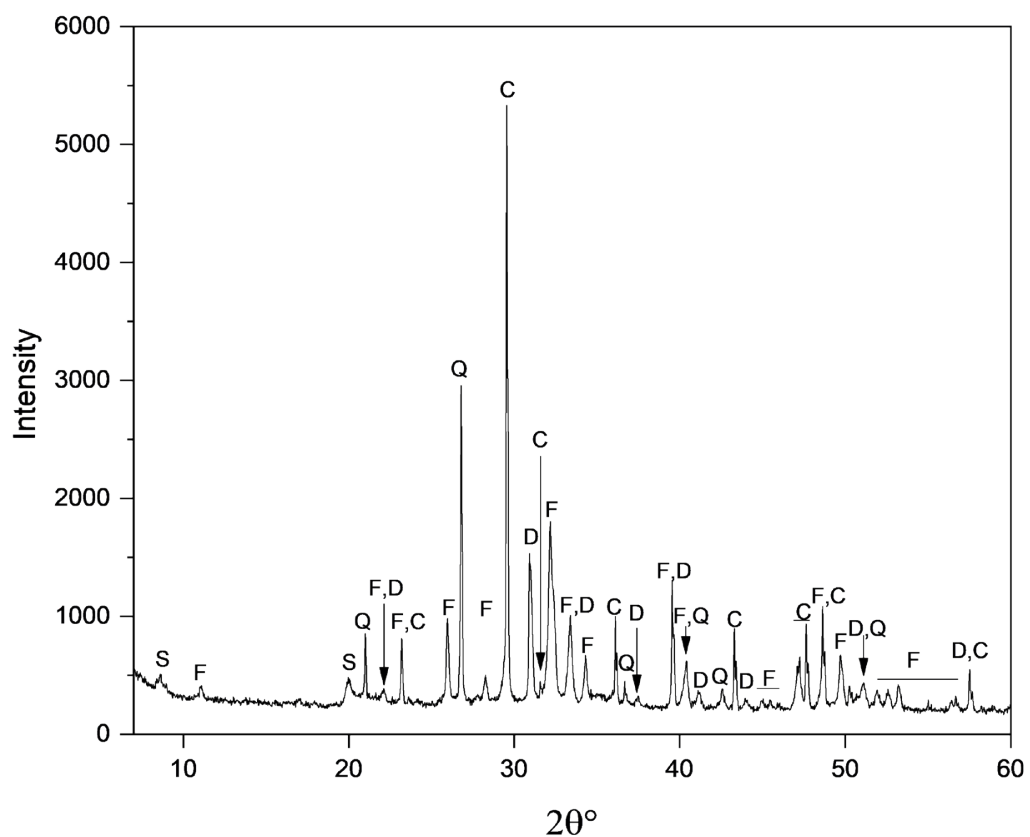

FIGURE 4: X-ray diffraction pattern of PS [F: Carbonate fluorapatite (PDF\#01-073-9695); D: Dolomite (PDF \# 01-073-2361); Q: Quartz (PDF \# 01-074-3485); C: Calcite (PDF \#0 1-085-1108) ; and S: Smectite (PDF \# 29-1498)]. 
ter-soluble and could be sources of macro- and micronutrients (Dixon, 1992).

\subsection{Thermal stability}

The thermal stability of PS components is evaluated by DTA, TGA and FTIR analysis. The resultant thermal events of PS (Figure 5) were presented by the weight loss (WL) curve (TGA) and heat flow curve (DTA). FTIR spectra reveal the chemical composition of PS at the end of each thermal event, particularly at $412,677,832,1000^{\circ} \mathrm{C}$ (Figure 6). Significant changes appeared in the intensity from the original positions of raw PS absorbance bands (Table 2).

The DTA and TGA curves show an endothermic peak $\left(\mathrm{T}^{\circ}\right.$ $=105^{\circ} \mathrm{C}, \mathrm{WL}=3.95 \%$ ) associated with the disappearance of absorbance at $3614 \mathrm{~cm}^{-1}$ and a relative decrease at 3248, 3440 , and $3475 \mathrm{~cm}^{-1}$ in FTIR spectrum of raw PS. This could be attributed to the bending vibration of $-\mathrm{OH}$ groups in the water molecules, which indicates the loss of water (Loutou et al., 2013). In the temperature range between 171.5 and $413.6^{\circ} \mathrm{C}$, the DTA and TGA curves represent a weak endothermic peak $\left(\mathrm{T}^{\circ}=346^{\circ} \mathrm{C}, \mathrm{WL}=0.61 \%\right)$, which is associated with the OM degradation. Accordingly, the FTIR data of the PS sample at $412^{\circ} \mathrm{C}$ confirm the disappearance of the corresponding bands $\left(2985\right.$ and $\left.2862 \mathrm{~cm}^{-1}\right)$ of the symmetrical and asymmetrical vibration of the $\mathrm{CH}$ aliphatic groups $\left(-\mathrm{CH}_{2}\right.$ and $\left.-\mathrm{CH}_{3}\right)$ (Amir et al., 2008). The large endothermic peak $\left(\mathrm{T}^{\circ}=492^{\circ} \mathrm{C}, \mathrm{WL}=3.16 \%\right)$ refers to the dehydroxylation of smectite (Hajjaji et al., 2001). This event is linked to a decrease in the intensity of the band located between 3100 and $3700 \mathrm{~cm}^{-1}$, which corresponds to hydroxyl stretching and deformation of Al-Al-OH of smectite. From $712^{\circ} \mathrm{C}$ to $1000^{\circ} \mathrm{C}$, a strongly endothermic decomposition reaction of carbonate compounds occurred at $836^{\circ} \mathrm{C}$ recorded in the DTA curve and accompanied by a significant WL of $13.14 \%$ due to the release of $\mathrm{CO}_{2}$. This phenomenon was characterized by a decrease in the intensity of structures absorbing at 1416,1043, and $877 \mathrm{~cm}^{-1}$ and the disappearance of absorbance bands at 2515 and $720 \mathrm{~cm}^{-1}$ in FTIR spectrum of PS treated at $832^{\circ} \mathrm{C}$. These frequencies are assigned to the $\mathrm{CO}_{2}{ }^{3-}$ groups of dolomite, calcite, and carbonate fluorapatite. After that, no significant changes occurred in the PS sample, and the same absorbance peaks were recorded in the FTIR spectrum at $1000^{\circ} \mathrm{C}$.

These results confirm the XRD characterization of the mineralogical composition of PS (dolomite, calcite, quartz, smectite, and carbonate fluorapatite) and reveal the aliphatic structure of OM contained in PS. The aliphatic structure of $\mathrm{OM}$ is considered a readily available energy source for soil microorganisms (Amir et al., 2004).

\subsection{Pathogenicity and phytotoxicity}

In order to reduce the potential health risks associated with pathogens, potentially pathogenic organisms have been counted in PS, and the results were presented in Table 3. Fecal coliforms, Escherichia coli, fecal streptococci, Staphylococcus aureus, Salmonella have been classified as pathogenicity indicators of substrates intended for agricultural use. As there are no limit values or requirements for pathogens in phosphate materials for agricultural application, a comparison with organic fertilizers legislation is valid. The results confirm that the levels of pathogens in the PS are under the detection limit, or far below the limits set by most European countries for biosolids used for agriculture (Collivignarelli et al., 2019).

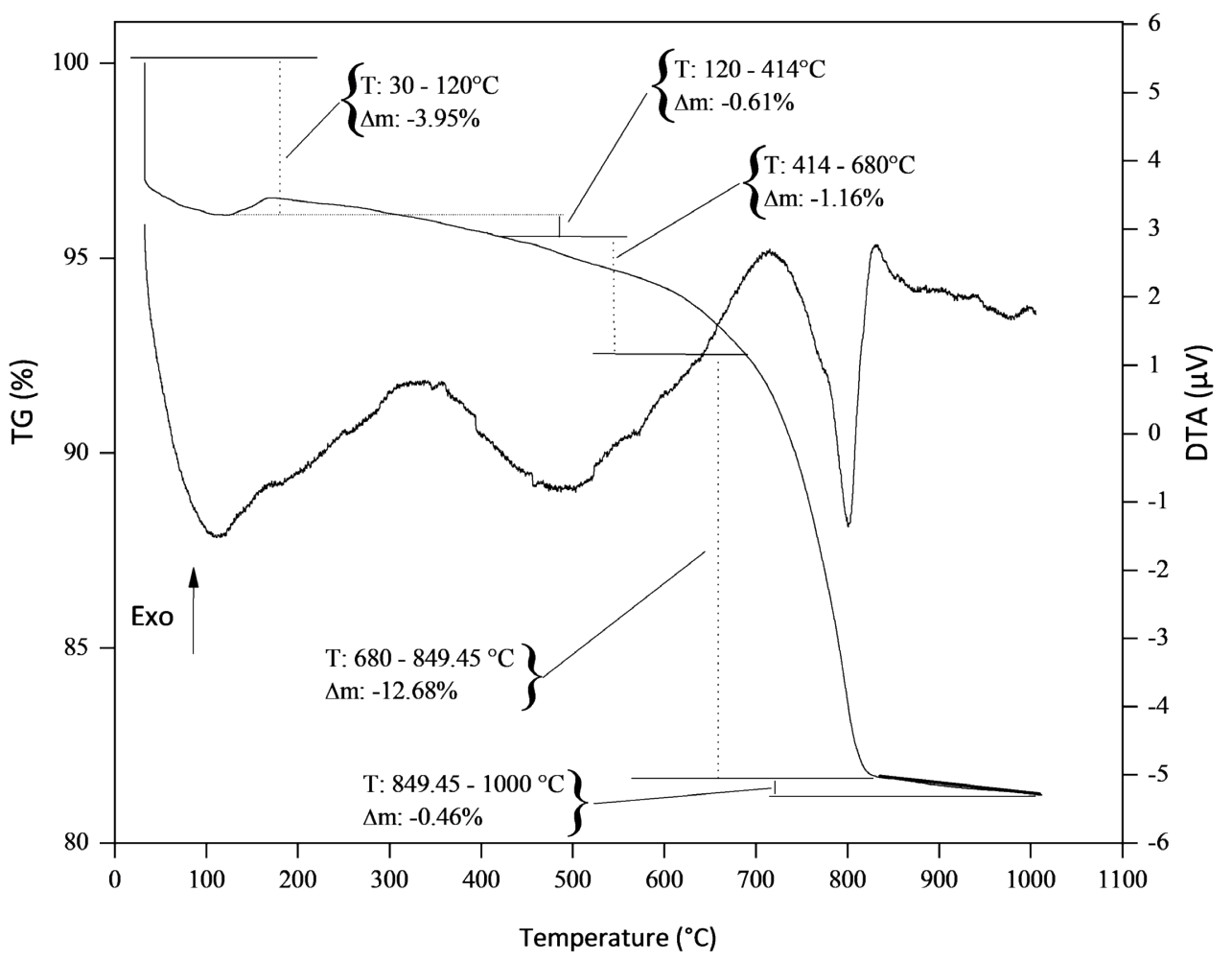

FIGURE 5: TGA and TDA curves. 


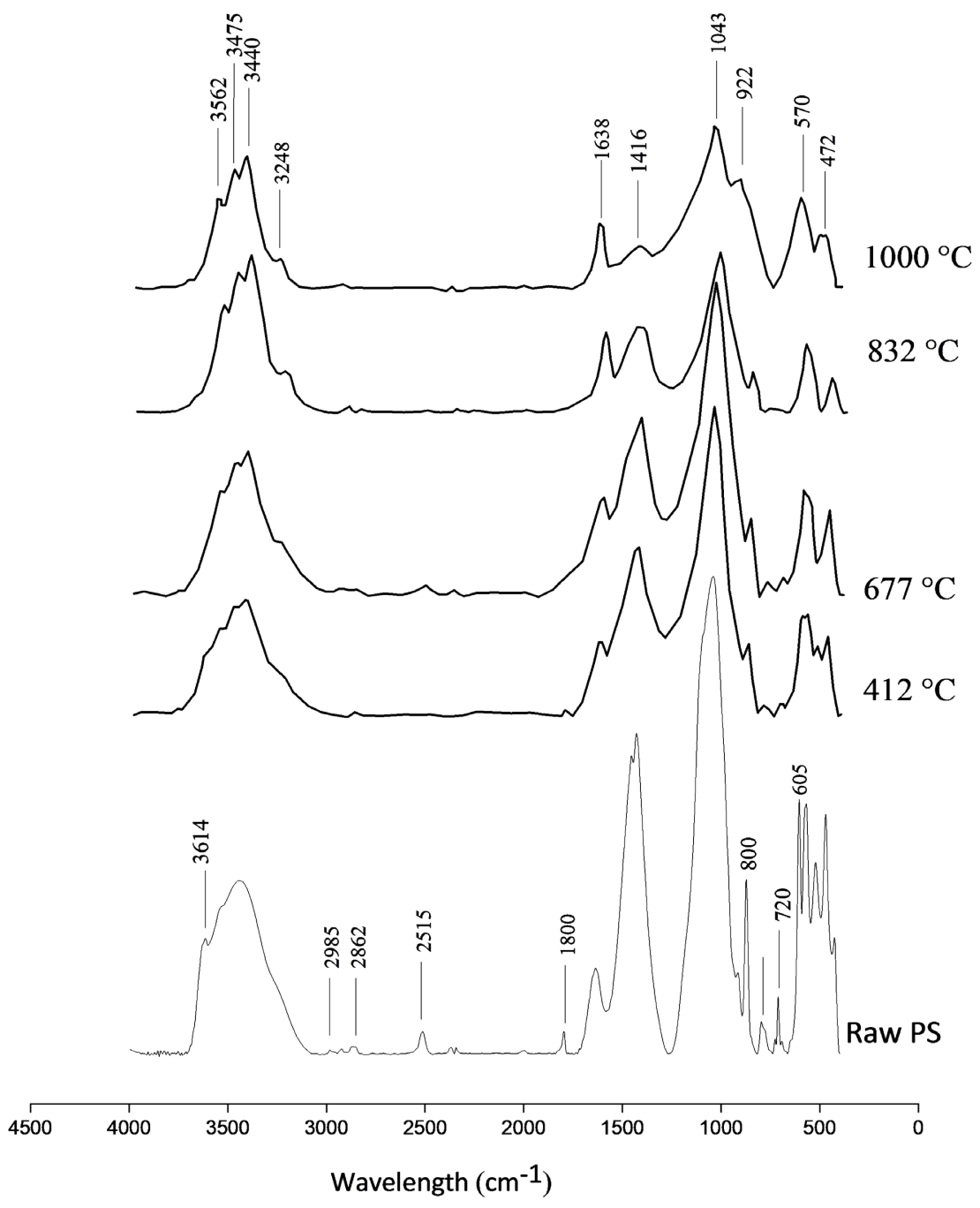

FIGURE 6: FTIR analysis of PS.

The results of the germination test carried out using tomato and maize seeds germinated in PS extract were presented in Figure 7. Several authors reported that a GI greater than $50 \%$ was a good indicator for non-phytotoxic samples (Levy and Taylor, 2003; Haouas et al., 2021b). The main factors leading to the inhibition of seed germination are high concentrations of salts, certain heavy metals (e.g., arsenic (As), $\mathrm{Pb}, \mathrm{Cd}$, and $\mathrm{Cr}$ ), and toxic organic compounds (e.g., polyphenols and organic acids) (Martínez-Ballesta et al., 2020). The PS extract exhibited no phytotoxic effect on maize and tomato seeds as their $\mathrm{Gl}$ values exceeded $50 \%$ (Figure 7). This ability of PS to germinate maize and

TABLE 2: The main absorbance bands of PS in FTIR spectra and their assignments.

\begin{tabular}{l|l}
\hline Bands and peaks $\left(\mathbf{c m}^{-1}\right)$ & Assignments \\
\hline 922 and $570 \mathrm{~cm}^{-1}$ & Symmetric stretching of $\mathrm{PO}_{4}{ }^{3-}$ of Carbonate fluorapatite \\
\hline $1416,1043,2515,877$ and $720 \mathrm{~cm}^{-1}$ & $\mathrm{CO}_{2}{ }^{3-}$ groups of dolomite, calcite and carbonate fluorapatite \\
\hline 2985 and $2862 \mathrm{~cm}^{-1}$ & $-\mathrm{CH}_{2}$ and $-\mathrm{CH}_{3}$ of aliphatic groups \\
\hline $3475,3440,3248$, and $3614 \mathrm{~cm}^{-1}$ & $-\mathrm{OH}$ groups in the water molecules and hydroxyl stretching and deformation of Al-Al-OH of smectite \\
\hline $800 \mathrm{~cm}^{-1}$ & $\mathrm{Si}-\mathrm{O}-\mathrm{Si}$ symmetrical stretching vibration of quartz \\
\hline
\end{tabular}

The assignments are based on numerous studies (Regnier et al., 1994; Ojima et al., 2003; Amir et al., 2010; Loutou et al., 2013).

TABLE 3: Enumeration of pathogens in PS.

\begin{tabular}{l|ccccc} 
Types of Pathogens & Fecal Coliforms $\left(\times \mathbf{1 0}^{2}\right)$ & Escherichia Coli $\left(\times 10^{3}\right)$ & Fecal Streptococci $\left(\times 10^{2}\right)$ & Staphylococcus aureus \\
\hline $\begin{array}{l}\text { Average concentration } \\
\text { (CFU /g fresh weight) }\end{array}$ & $0.12 \pm 0.003$ & $0.02 \pm 0.001$ & $0.03 \pm 0.001$ & Salmonella \\
\hline
\end{tabular}


tomato seeds is due to the absence of phytotoxic factors and the presence of available nutrients (Martínez-Ballesta et al., 2020). It was reported that many nutrients found in PS improved seeds germination of many crops, including $P$ and nitrogen $(\mathrm{N})$ as macronutrients and molybdenum (Mo), boron (B), manganese (Mn), Zn as micronutrients (Imran et al., 2017; Rehman et al., 2018).

\subsection{Plant growth promotion capacity}

Plants grown in treatments and control have survived, and no plant death has been observed. Figure 8 indicates the appearance of randomly selected plants (one plant from each treatment and control). The effect of PS on plant growth was assessed by comparing the data obtained after the measurement of the growth parameters (root length, root dry and fresh weight, shoot height, shoot dry and fresh weight and the number of lived leaves), and the results were presented in Figure 9 and 10.

The results related to the root part (Figure 9) show that the plants cultivated in the soil amended with $20 \%$ of PS had higher root length $(29 \mathrm{~cm})$ than other PS treatments and control. However, there was no significant difference in root length values (from 26.7 to $29 \mathrm{~cm}$ ) between plants developed in $1,10,20,40$, and $50 \%$ of PS treatments. The concentration of $60 \%$ of PS in deficient soil recorded the lowest value of $15.7 \mathrm{~cm}$. The application of PS to the soil could enhance the fresh weight of roots. In fact, Figure 9 shows a slight increase of root fresh weight ranged from 5.14 to $5.68 \mathrm{~g}$ in treatments prepared with $1,5,10$, and $20 \%$ of PS, compared to control ( $0 \%$ of PS). For root dry weight, the control plants showed a maximum value of $1.54 \mathrm{~g}$ with a significant difference $(p<0.05)$ in PS treatments. While,

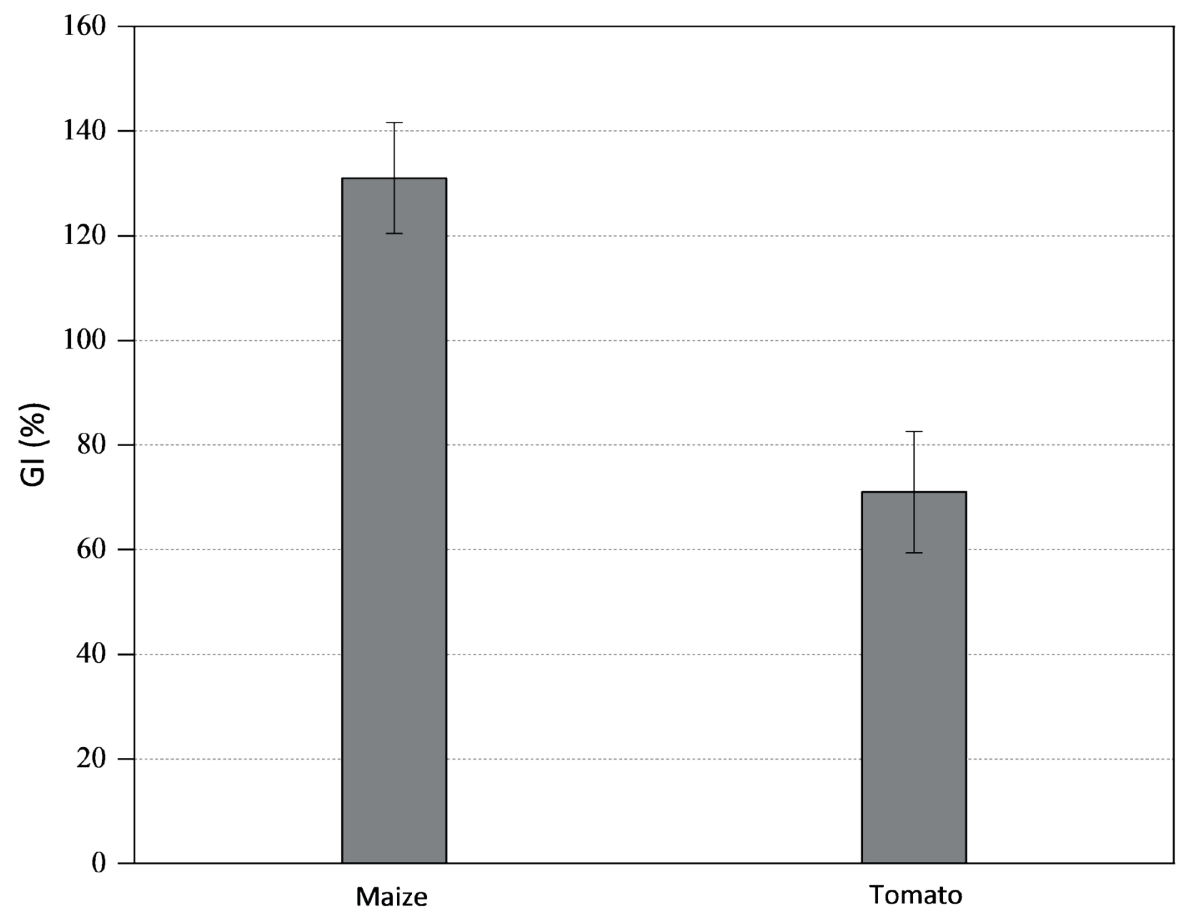

FIGURE 7: The GI of the tomato seeds in the PS extract.

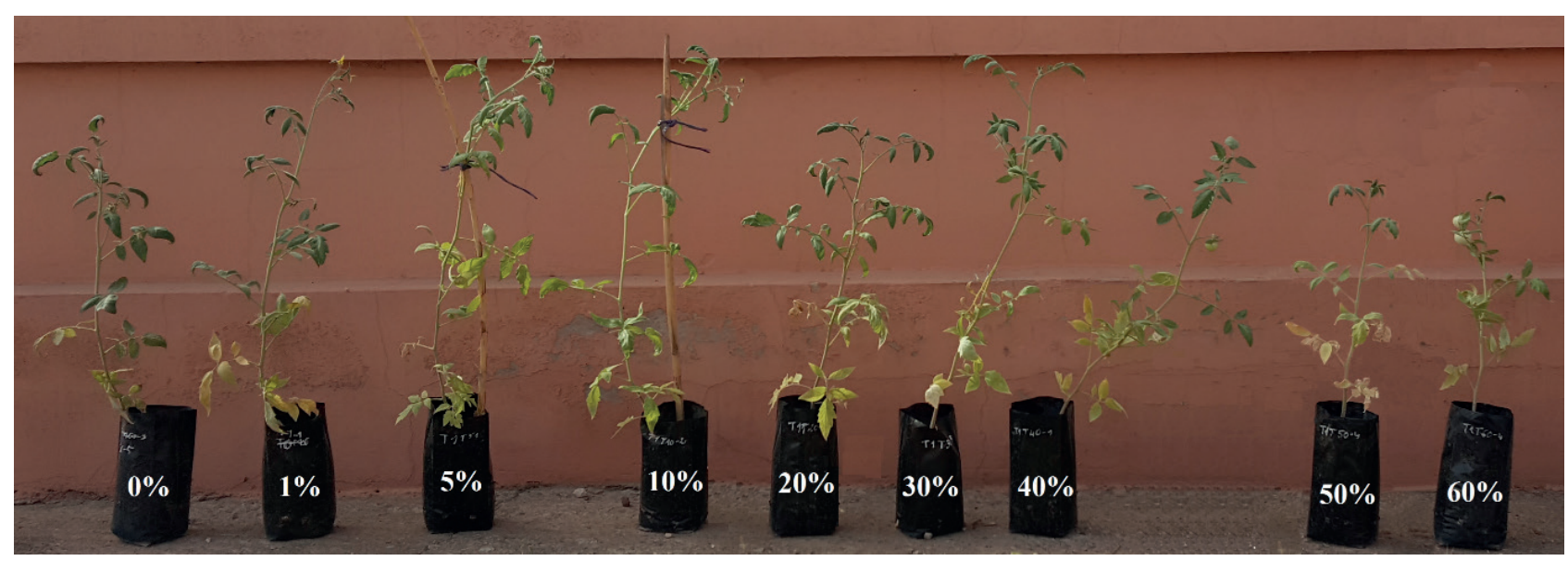

FIGURE 8: Appearance of tomato plants after 80 days of growth in soil amended with different concentrations of PS. 

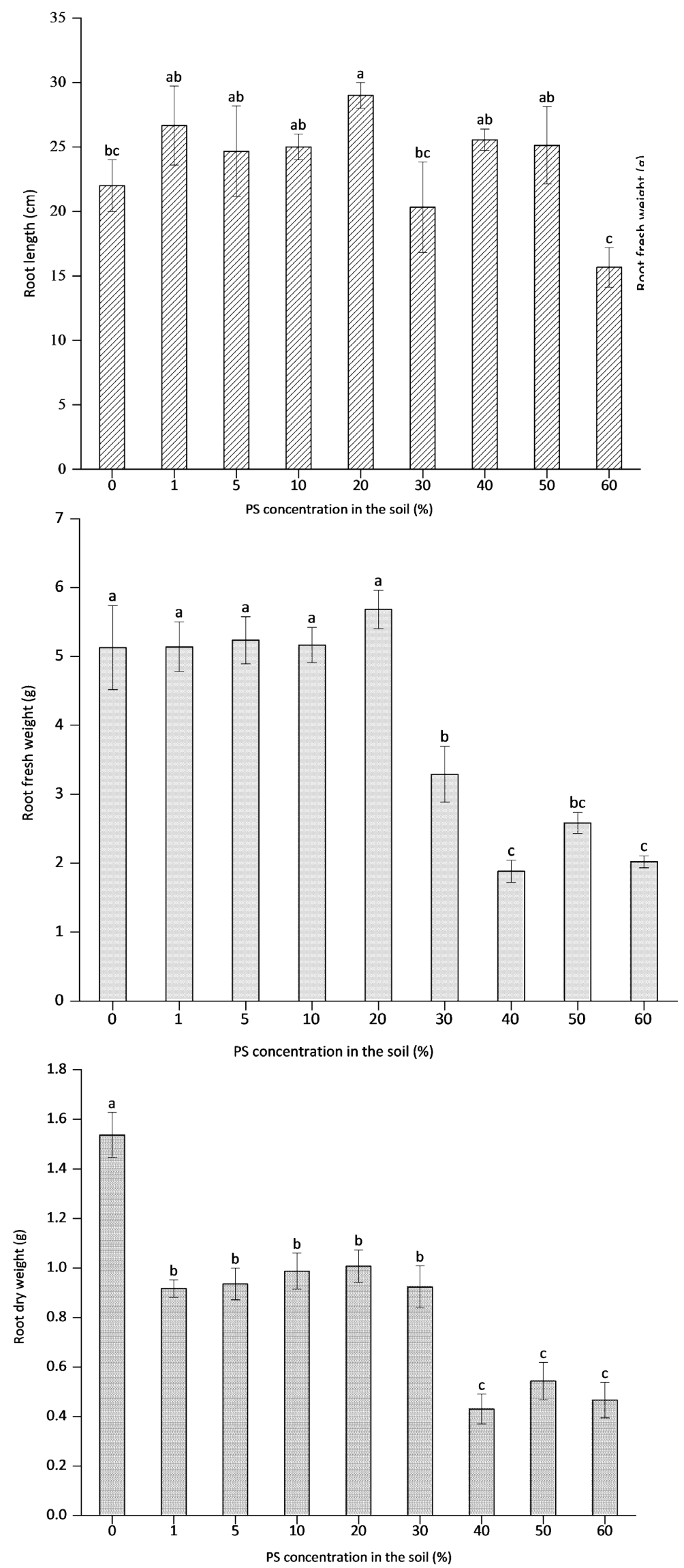

FIGURE 9: Length, fresh weight, and dry weight of the root part after 80 days of tomato plants grown in deficient soil amended with different concentrations of PS. 

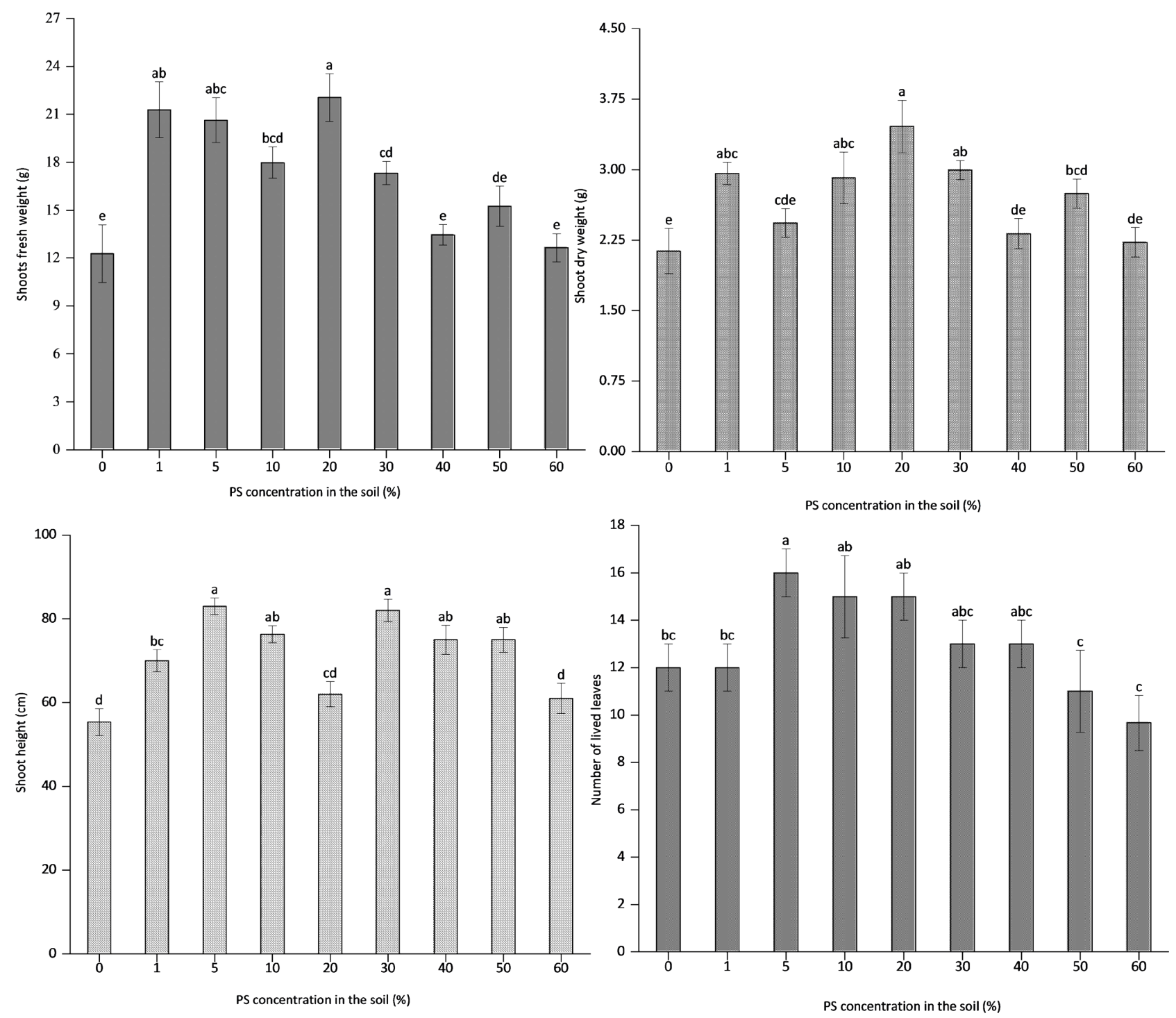

FIGURE 10: Height, fresh weight, dry weight, and the number of lived leaves of the shoot part after 80 days of tomato plants grown in deficient soil amended with different concentrations of PS.

high PS concentrations of 40,50 , and $60 \%$ recorded the lowest weight of root biomass (fresh and dry weight) of tomato plants.

The results related to the shoot part (Figure 10) show that the addition of PS to sandy soil increased the fresh weight, dry weight, and height of the plant shoots. Plants at concentrations of $1,5,10,20$, and $30 \%$ of PS had the highest shoot fresh weight of between 17.32 and 22.06 g. The application of PS at $20 \%$ significantly increased ( $p$ $<0.05$ ) the shoot biomass compared to other concentrations of PS. While control plants showed the lowest values of $12.28 \mathrm{~g}$ and $2.13 \mathrm{~g}$ in fresh and dry weight, respectively. In addition, a significant effect of the PS amendment was observed on plant height and the number of lived leaves. In treatments of $1,5,10,30,40$, and $50 \%$ of PS, recorded the highest values of shoot height fluctuated between 83 and $70 \mathrm{~cm}$. In control with only soil, the value of shoot height was $55.3 \mathrm{~cm}$. Concentrations from 5 to $40 \%$ of PS added to the deficient soil increased the number of leaves of tomato plants (ranged from 13 to 16) compared to control (12 leaves). In contrast, the lowest number of leaves was registered in plants grown in the amended soil at 50 and $60 \%$ of PS.

PS at a concentration of $20 \%$ significantly improved root elongation, shoot fresh weight, and shoot dry weight and a concentration of $5 \%$ induced higher shoot height and number of lived leaves compared to control. In contrast, concentrations of up to $40 \%$ of PS $(40,50$, and $60 \%)$ showed poor plant development and reduced root biomass compared to control. The enhancement of plant growth in the presence of PS amendments could be due to improved soil agronomic properties, leading to increased water and nutrient availability (Belay et al., 2020). The PS clay minerals may increase sandy soil's chemical and physical properties, making the water readily available for plant roots, leading to strong roots and tall and healthy shoots (Kay- 
ama et al., 2016). It has been shown that clay addition to the sandy soil increased significantly 2.5 times the yield of maize (Gold dent KD 777) and cucumber (Shin toki wa) and also by $12.8 \%$ of squash (Cucurbita Pepo) compared to control (Ismail and Ozawa, 2007; Al-Omran et al., 2005).

The growth parameters (Figure 9, 10) reveal that the control plants were less developed than PS treatments, especially at $20 \%$ and $5 \%$. This phenomenon could be attributed to the water shortage of the sandy soil used. The water deficit for plant uptake has been found to have a large impact on many cultivars, including tomato plants (Ximénez-Embún et al., 2018). In fact, it has been reported that clay-rich materials application in sandy soils increased the cropping yield due to improved water holding capacity (Ismail and Ozawa, 2007). However, incorporating a large quantity of clay-rich materials may negatively affect plant growth, as stated in this study, when the PS concentration exceeded $40 \%$ and mainly at $60 \%$. Excess of clay fraction into the soil may cause several adverse effects when irrigated, such as waterlogging, which has led to roots asphyxiation and the reduction respiration activity of soil microorganisms (Gil et al., 2011). As reported in this study, smectite is the major fraction of PS clay minerals, which, due to its physical properties such as fine particle size, high surface area, and variable interlayer spacing, it could be the main responsible for clay effect on plant growth at $60 \%$ of PS (Dixon, 1991). On the other hand, the lack of nutrients and water states in the soil induces plants to develop deep and strong roots in search of water pockets and nutrients along with short and weak shoots, as stated in this study for plants cultivated in only sandy soil (control) (Hermans et al., 2006).

\section{CONCLUSIONS}

The characterization of PS is crucial to determine their benefit and potential risk criteria for farming soil. PS is a stable material with a high nutrient content such as $\mathrm{P}, \mathrm{Ca}$, and $\mathrm{Mg}$. In addition, PS mineral clays had beneficial properties for improving the performance of deficient sandy soils, such as high water holding capacity and a slow release of nutrients compared to chemical fertilizers. PS was therefore shown to be free of pathogens and phytotoxic substances, indicating a low risk of contamination of the harvested products. Consequently, the use of a PS concentration of $20 \%$ is highly recommended. Thus, it should be combined with organic-rich material such as compost to replenish the low OM content in PS.

\section{ACKNOWLEDGMENTS}

The Authors would like to acknowledge the support through the R\&D Initiative - Appel à projets autour des phosphates APPHOS - sponsored by OCP (OCP Foundation, R\&D OCP, Mohammed VI Polytechnic University, National Center of Scientific and technical Research CNRST, Ministry of Higher Education, Scientific Research and Professional Training of Morocco MESRSFC) under the project entitled «Procédés biotechnologiques pour la valorisationdes boues et des déchets miniers de phosphate:
Formulation d'un Phospho-compost bio-fertilisant pour application directe en agriculture productive et respectueuse de l'environnement» (Réf. BIO-MOD-01/2017).

\section{COMPETING INTERESTS}

Authors have declared that no competing interests exist.

\section{REFERENCES}

AFNOR, 2000. Soil amendments and growing medium - Preparation of samples for physical and chemical testing, determination of dry matter content, moisture content and compacted density in the laboratory (in French). AFNOR France, NF EN 13040.

Al-Omran, A.M., Sheta, A.S., Falatah, A.M. and Al-Harbi, A.R., 2005. Effect of drip irrigation on squash (Cucurbita Pepo) yield and water use efficiency in sandy calcareous soils amended with clay deposits. Agric. Water Manag. 73, 43-55.

Amir, S., Hafidi, M., Merlina, G., Hamdi, H., Revel, J.C., 2004. Elemental analysis, FTIR and 13C-NMR of humic acids from sewage sludge composting. Agronomie 24, 13-18. https://doi.org/10.1051/ agro:2003054

Amir S., Hafidi M., Merlina G, Revel J.C., 2005. Sequential extraction of heavy metals during composting of sewage sludge. Chemosphere 59, 6, 801-810. https://doi. 10.1016/j.chemosphere. 2004.11.016.

Amir, S., Benlboukht, F., Cancian, N., Winterton, P., Hafidi, M., 2008. Physico-chemical analysis of tannery solid waste and structural characterization of its isolated humic acids after composting. J. Hazard. Mater., 160, 2-3, 448-455. https://doi. 10.1016/j. jhazmat.2008.03.017

Anne, P., 1945. Sur le dosage du carbone organique des sols Ann. Agron., 15, 161-172.

Atif, K., Haouas, A., Aziz, F., Yasser Jamali, M., Tallou, A., \& Amir, S., 2020. Pathogens Evolution During the Composting of the Household Waste Mixture Enriched with Phosphate Residues and Olive Oil Mill Wastewater. Waste and Biomass Valorization. 11, 1789-1797. https://doi.org/10.1007/s12649-018-0495-3

Belay, S.A., Assefa, T.T., Prasad, P.V.V., Schmitter, P., Worqlul, A.W., Steenhuis, T.S., Reyes, M.R., Tilahun, S.A., 2020. The Response of Water and Nutrient Dynamics and of Crop Yield to Conservation Agriculture in the Ethiopian Highlands. Sustainability 12, 5989. https:// doi.org/10.3390/su12155989

Boujlel, H., Daldoul, G., Tlil, H., Souissi, R., Chebbi, N., Fattah, N., \& Souissi, F., 2019. The Beneficiation Processes of Low-Grade Sedimentary Phosphates of Tozeur-Nefta Deposit (Gafsa-Metlaoui Basin: South of Tunisia). Minerals, 9(1), 2. https://doi.org/10.3390/ $\min 9010002$

Bray, R.H. and Kurtz, L.T., 1945. Determination of Total Organic and Available Forms of Phosphorus in Soils. Soil Sci., 59, 39-45. http:// dx.doi.org/10.1097/00010694-194501000-00006

Chang, S. C., \& Jackson, M. L., 1957. Fractionation of Soil Phosphorus. Soil Sci., 84, 133-144. https://doi.org/10.1097/00010694195708000-00005

Chen, Y.X., Huang, X.D., Han, Z.Y., Huang, X., Hu, B., Shi, D.Z., \& Wu, W.X., 2010. Effects of bamboo charcoal and bamboo vinegar on nitrogen conservation and heavy metals immobility during pig manure composting. Chemosphere, 78(9), 1177-1181. https://doi. org/10.1016/j.chemosphere.2009.12.029

Collivignarelli, M. C., Abbà, A., Frattarola, A., Carnevale Miino, M., Padovani, S., Katsoyiannis, I., \& Torretta, V., 2019. Legislation for the Reuse of Biosolids on Agricultural Land in Europe: Overview. Sustainability, 11(21), 6015. https://doi.org/10.3390/su11216015

Dixon, J.B., 1991. Roles of clays in soils. Appl. Clay Sci. 5, 489-503. https://doi.org/10.1016/0169-1317(91)90019-6

FAO, 2009. Climate change in Africa: The threat to agriculture. https:// www.uncclearn.org/sites/default/files/inventory/fao34.pdf. Accessed 26 December 2019

FAO-UNESCO, 1999. World Soil Map, revised legend, Rome

Gil, P.M., Ferreyra, R., Barrera, C., Zuniga, C., Gurovich, L.A., 2011. Improving soil oxygenation with hydrogen peroxide injection into heavy clay loam soil: effect on plant water status, $\mathrm{CO} 2$ assimilation and biomass of avocado trees. Acta Hortic. 
Hajjaji, M., Kacim, S., Alami, A., El Bouadili, A., El Mountassir, M., 2001. Chemical and mineralogical characterization of a clay taken from the Moroccan Meseta and a study of the interaction between its fine fraction and methylene blue. Applied Clay Sci. 20, 1e12.

Hakkou, R., Benzaazoua, M., Bussière, B., 2016. Valorization of Phosphate Waste Rocks and Sludge from the Moroccan Phosphate Mines: Challenges and Perspectives. Procedia Engineering, SYMPHOS 2015 - 3rd International Symposium on Innovation and Technology in the Phosphate Industry 138, 110-118. https://doi. org/10.1016/j.proeng.2016.02.068

Haouas, A., El Modafar, C., Douira, A., Ibnsouda-koraichi, S., Filali-maltouf, A., Moukhli, A., Amir, S., 2020. The effect of phosphate and organic additives on the stability of food waste in the full-scale composting. PLANT CELL BIOTECHNOLOGY AND MOLECULAR BIOLOGY 21 (39-40), 17-28. https://ikprress.org/index.php/ PCBMB/article/view/5428.

Haouas, A., El Modafar, C., Douira, A., Ibnsouda-Koraichi, S., FilaliMaltouf, A., Moukhli, A., Amir, S., 2021a. Alcaligenes aquatilis GTE53: Phosphate solubilising and bioremediation bacterium isolated from new biotope "phosphate sludge enriched-compost." Saudi J. Biol. Sci. 28, 371-379. https://doi.org/10.1016/j. sjbs.2020.10.015

Haouas, A., El Modafar, C., Douira, A., Ibnsouda-Koraichi, S., Filali-Maltouf, A., Moukhli, A., Amir, S., 2021b. Evaluation of the nutrients cycle, humification process, and agronomic efficiency of organic wastes composting enriched with phosphate sludge. J. Clean. Prod. 302, 127051. https://doi.org/10.1016/j.jclepro.2021.127051

Hermans, C., Hammond, J.P., White, P.J., Verbruggen, N., 2006. How do plants respond to nutrient shortage by biomass allocation?. Trends Plant Sci. 11, 610-617. https://doi.org/10.1016/j. tplants.2006.10.007

Imran, M.; Volker, R.; Neumann, G., 2017. Accumulation and distribution of $\mathrm{Zn}$ and $\mathrm{Mn}$ in soybean seeds after nutrient seed priming and its contribution to plant growth under $\mathrm{Zn}$ and $\mathrm{Mn}$ deficient conditions. J. Plant Nutr. 40, 695-708.

Ismail, S.M. and Ozawa, K., 2007. Improvement of crop yield, soil moisture distribution and water use efficiency in sandy soils by clay application. Appl. Clay Sci. 37, 81-89. https://doi.org/10.1016/j. clay.2006.12.005

Karunanithi, R., Szogi, A. A., Bolan, N., Naidu, R., Loganathan, P., Hunt, P. G., et al., 2015. Chapter Three - Phosphorus Recovery and Reuse from Waste Streams. In D. L. Sparks (Ed.), Advances in Agronomy (Vol. 131, pp. 173-250). Academic Press. https://doi.org/10.1016/ bs.agron.2014.12.005

Kayama, M., Nimpila, S., Hongthong, S., Yoneda, R., Wichiennopparat W., Himmapan, W., Vacharangkura, T., Noda, I., 2016. Effects of Bentonite, Charcoal and Corncob for Soil Improvement and Growth Characteristics of Teak Seedling Planted on Acrisols in Northeast Thailand. Forests 7, 36. https://doi.org/10.3390/f7020036

Khasawneh, F. E., \& Doll, E. C., 1979. The Use of Phosphate Rock for Direct Application to Soils. In N. C. Brady (Ed.), Adv. Agron. (Vol. 30, pp. 159-206). Academic Press. https://doi.org/10.1016/S00652113(08)60706-3
Kihara, J., Bolo, P., Kinyua, M., Rurinda, J., Piikki, K., 2020. Micronutrient deficiencies in African soils and the human nutritional nexus: opportunities with staple crops. Environ Geochem Health 42, 30153033. https://doi.org/10.1007/s10653-019-00499-w

Levy, J.S., \& Taylor, B.R., 2003. Effects of pulp mill solids and three composts on early growth of tomatoes. Bioresour. Technol. 89, 297-305. https://doi.org/10.1016/S0960-8524(03)00065-8

Loutou, M., Hajjaji, M., Mansori, M., Favotto, C., \& Hakkou, R., 2013. Phosphate sludge: thermal transformation and use as lightweight aggregate material. J. Environ. Manage. 130, 354-360. https://doi. org/10.1016/j.jenvman.2013.09.004

Luo, Y., Liang, J., Zeng, G., Chen, M., Mo, D., Li, G., Zhang, D., 2018 Seed germination test for toxicity evaluation of compost: Its roles, problems and prospects. Waste Manag 71, 109-114. https://doi. org/10.1016/j.wasman.2017.09.023

Martínez-Ballesta, M. del C., Egea-Gilabert, C., Conesa, E., Ochoa, J., Vicente, M.J., Franco, J.A., Bañon, S., Martínez, J.J., Fernández, J.A., 2020. The Importance of Ion Homeostasis and Nutrient Status in Seed Development and Germination. Agronomy 10, 504. https:// doi.org/10.3390/agronomy10040504

Moukannaa, S., Loutou, M., Benzaazoua, M., Vitola, L., Alami, J., \& Hakkou, R., 2018. Recycling of phosphate mine tailings for the production of geopolymers. J. Clean. Prod. 185, 891-903. https://doi. org/10.1016/j.jclepro.2018.03.094

Ojima, J., 2003. Determining of Crystalline Silica in Respirable Dust Samples by Infrared Spectrophotometry in the Presence of Interferences. J. Occup. Health 45, 94-103. https://doi.org/10.1539/ joh.45.94

Regnier, P., Lasaga, A.c., Berner, R.A., Han, O.H., and Zilm, K.W., 1994. Mechanism of COj- substitution in carbonate-fluorapatite: Evidence from FTIR spectroscopy, I3C NMR, and quantum mechanical calculations. Am. Mineral. 79, 809-818.

Rehman, A.; Farooq, M.; Naveed, M.; Nawaz, A.; Shahzad, B., 2018. Seed priming of $\mathrm{Zn}$ with endophytic bacteria improves the productivity and grain biofortification of bread wheat. Eur. J. Agron. 94, 98107.

Romanos, D., Nemer, N., Khairallah, Y., \& Abi Saab, M. T., 2019. Assessing the quality of sewage sludge as an agricultural soil amendment in Mediterranean habitats. Int. j. recycl. org. waste agric. 8(1), 377383. https://doi.org/10.1007/s40093-019-00310-x

Tallou, A., Salcedo, F.P., Haouas, A., Jamali, M.Y., Atif, K., Aziz, F., Amir, S., 2020. Assessment of biogas and biofertilizer produced from anaerobic co-digestion of olive mill wastewater with municipal wastewater and cow dung. Environ Technol Inno 20, 101152. https:// doi.org/10.1016/j.eti.2020.101152

Ximénez-Embún, M.G., González-Guzmán, M., Arbona, V., Gómez-Cadenas, A., Ortego, F., Castañera, P., 2018. Plant-Mediated Effects of Water Deficit on the Performance of Tetranychus evansi on Tomato Drought-Adapted Accessions. Front. Plant Sci. 9. https://doi. org/10.3389/fpls.2018.01490

Zhang, L., Sun, X., 2017. Addition of fish pond sediment and rock phosphate enhances the composting of green waste. Bioresour. Technol. 233, 116-126. https://doi.org/10.1016/j.biortech.2017.02.073 